\title{
A creative economy: \\ Design with cultural value as an income opportunity for developing countries
}

\author{
Florencia Adriasola / Universidad Diego Portales / Santiago / Chile
}

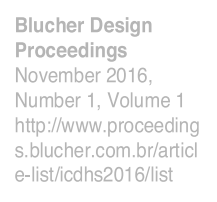

\begin{abstract}
This paper reflects on the role that Design plays in the success of local economies by promoting cultural and/or emotional values in their exports. Donald Norman and Bruno Latour's theories will be discussed. Latin American economies are experiencing a tighter integration with Asia, based primarily on exports of finite natural resources; generating opportunities, but not without risks. The main case study is the Chilean Economy: flourishing but based on the export of raw materials, especially copper. China is its main buyer, making the countries vulnerable and dependent. Nevertheless, this market opportunity offers the chance to acquire capital to invest in other sectors and diversify industries; for instance, Creative Industries like Design can strengthen a country's image, creating exports, which incorporate local narratives, generating protection for the land and rural populations. In sum, Design, can add emotional value to raw materials and expand the international market for regional design.
\end{abstract}

\section{Keywords}

Developing Economies, Cultural Values, Economic Dependency Latin America, Asia, Chile

\section{Economic dependency on raw materials: Latin America-Asia}

"Peripheral countries" have historically provided raw materials in a model that emerged in the sixteenth century. First were Spain and Portugal then the Dutch Republic, France and, England. This changed in the twentieth century when United States also participated by adding high-value in production. But this has moved towards a more complex integration in the last decades, incorporating high-end cognitive cultural activities in advanced economies in North America and Europe but that can be also found in Asia, Latin America and parts of Africa These new leading sectors constitute strategic nodes in global networks, interconnected through flows of goods, services, knowledge and people. It is obviously hard to disentangle the web of causal factors behind this sea change in the world economy, but two interrelated factors can be singled out, namely technological change, which can be attributed to the Information and Communications Technology (ICT) revolution (Lambregts, B., Beerepoot, N., \& Kloosterman, R, 2016).

"Peripheral countries" have always exported raw materials, but they now have the chance to integrate other market exchanges that bring other opportunities, if we think that economies that are only supported on raw materials face different risks. Bruno Latour (Philosopher, Anthropologist and Sociologist of Science) links psychology with economic growth; he believes that because our economic model needs growth, politicians and investors behave as if the environment is not affected. Creating a balance and assuming that resources are finite is imperative. Latour states that we do not confront the fact that human activity is the main factor for climate change. Facing this new disconnect, many of us move from admiration in front of the innocent forces of nature to complete despondency and even lend an ear to the climate deniers (Latour, 2011). He remarks: "The Economy is not the basis for the world finally revealed to everyone thanks to the benefits of globalization but a cancer whose metastases have gradually begun to infect the entire Earth" (Latour, 2013, p. 384).

Latin American examples like Venezuela and Chile, help to explain the risks and opportunities of that exchanges based primarily on commodities. According to Mark Turner (Analyst in Latin American stocks markets for Hallgarten and Company), Venezuela bases its economy in one commodity, oil. Depending on this, as does Chile on copper. Since 2004, the composition of Chilean copper exports has changed from $35 \%$ to $40 \%$ of its total exports and up to $60 \%$ in late 2007. Moreover, the Central Bank of Chile (CBCh) said that the quantity of copper exported 


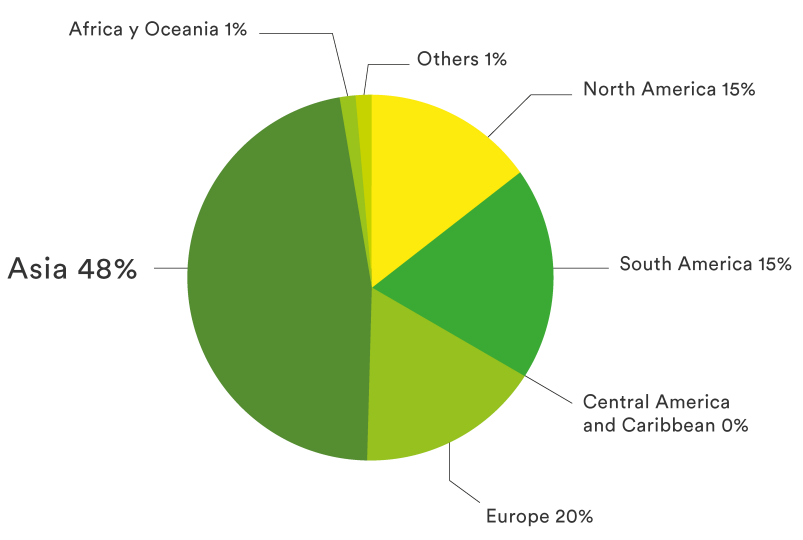

Fig. 1: Chile's main buyers (2010-2011). Central Bank, cited in ProChile, 2012

Asia-Pacific Economic Cooperation (APEC) serves as a bridge between these regions. For example, China's involvement Latin America has dramatically increased, in the past fifteen years, China has gone from having no presence to being a leading trade partner of important economies as Brazil, Peru and Chile. (Strauss, 2012).

\begin{tabular}{|c|c|c|}
\hline Exports by sector & 2010 & 2011 \\
\hline Mining & 44,360 & 48,865 \\
\hline Copper & 37,617 & 40,333 \\
\hline Other mining activities & 6,743 & 8,532 \\
\hline Agriculture, livestock and forestry & 4,366 & 5,066 \\
\hline Fruit & 3,686 & 4,274 \\
\hline $\begin{array}{l}\text { Other agriculture, livestock, } \\
\text { forestry and commercial fishing }\end{array}$ & 680 & 792 \\
\hline Industrial & 22,171 & 27,480 \\
\hline Food, beverages and tobacco & 7,849 & 9,767 \\
\hline Salmon \& trout & 2,053 & 2,917 \\
\hline Agribusiness & 791 & 1,002 \\
\hline Wine & 1,561 & 1,732 \\
\hline Other foods & 3,444 & 4,116 \\
\hline Forestry and wood furniture & 1,881 & 2,222 \\
\hline Pulp and paper & 3,102 & 3,692 \\
\hline Pulp & 2,404 & 1,002 \\
\hline Other paper & 698 & 837 \\
\hline Chemicals & 4,829 & 6,105 \\
\hline Other industrial products & 4,510 & 5,695 \\
\hline TOTAL* & 70,897 & 81,411 \\
\hline
\end{tabular}

Fig. 2: Main exports by sector (2010-2011). Central Bank, May 2012, cited in ProChile, 2012 represents 35\% of the total GDP (Turner, 2006). Julia Strauss (Senior Lecturer in Chinese Politics, member of the Centre of Chinese Studies at SOAS University of London), mentioned that in order to grow, the industrialized economies of Asia require for the commodity exporters of Latin America to be able to supply. Since the early 1990s, Asia and Latin America have been the participants of an extraordinary global movement toward multilateral agreements, including the promotion or implementation of free trade agreements e.g. the Southern Common Market (MERCOSUR), the Andean community in Latin America (CAN), the Association of Southeast Asian Nations (ASEAN) and the Shanghai Security Organization (SCO), making negotiations and trades easier among them. Moreover, the

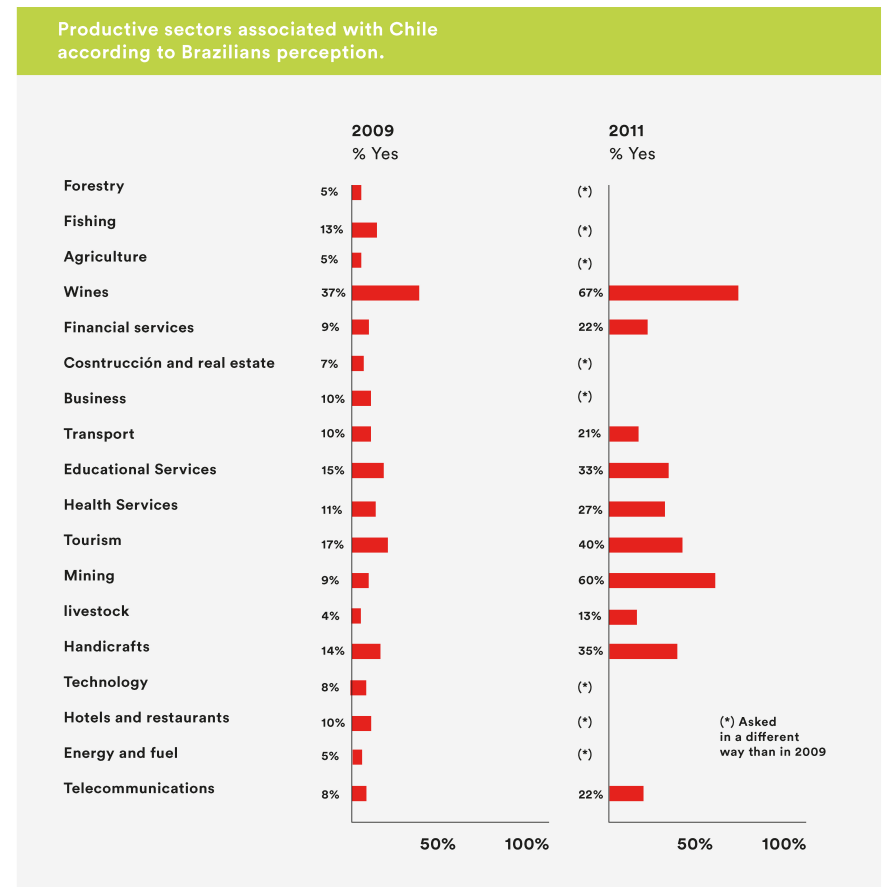

Fig. 3: Perception of Brazilians about Chile's productive sectors, Fundación Imagen de Chile

\section{The Chilean case}

Chile's case will be examined in-depth to explain the dangers and opportunities of an economy based on natural resources, with one main buyer. Copper has always been the main pillar of the Chilean economy, however, in past few years, this dependence became stronger (Turner, 2007). As Steven Anderson (Director, Global Human Resources Modular Mining Systems) explains, Chile is the world's main copper provider with over a $34 \%$ of the world supply in 2010. (Anderson, 2012), and China is its main fast-growing buyer due to the increasing demand for copper electrical wiring, and also for the manufacturing of other products.

As can be seen in the pie chart below in 2010 the recipients were led by Asia. ProChile also established that in 2011, Chile exported a total of USD 81,411 million and USD 40,333 million of it was copper.

In total, Chilean exports are ranked $45^{\text {th }}$ out of 222 countries, as stated by the Central Intelligence Agency (CIA), position that is competing with larger territories and populations, such as China and United States. Although this is an important position, Chile has not gained major recognition abroad as Elvira Chadwick 


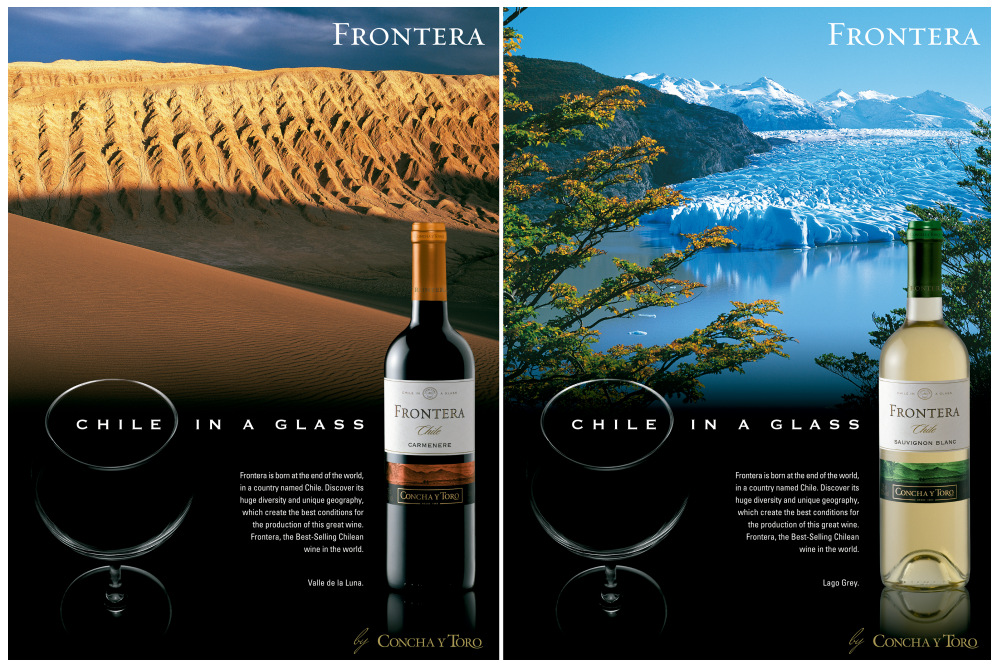

Fig. 4: Chilean wine, Frontera, promoted with landscapes of the country
(Chief in research at Fundación Imagen de Chile) mentioned in 2013.

As the previous graph shows, the majority of its exports are raw materials not connected with emotions or immaterial values. They are commodities lacking identity; sold mainly because they are the best or the cheapest; therefore, they do not help to create a strong country image. It could be concluded that it is risky to rely on just one resource, which could potentially be affected by different factors, as it happened to Chile with nitrate before.

The case of Nitrate is relevant to review; it was used as fertilizer and to create explosives, and for Chile, it was synonymous with

foreign investment and growth. "From 1880 until 1930, nitrate was the nation's main export. Chile gained control of the valuable [...] deposits in the War of the Pacific (1879-1883), but most of the nitrate exploitation was handled by British capital and in less extent by Germans" (Monteon M, 1982, p. 66). However, Chile obtained economic prosperity through exportation taxes (Lüders R, Wagner G, 2003).

After the start of the First World War, the British effectively blocked the Germans from the resource, so the latter created synthetic nitrate in 1918. This development put an end to the industry; luckily, copper became relevant, helping to mitigate the crisis. (Maskaev, 2001). This left behind ghost cities; some, like Humberstone and Santa Laura, became UNESCO protected in 2005 (UNESCO, 2003-2005). Although they are not inhabited today, their immaterial value is recognized. Thus, it can have emotional connections if associated with the workers narrative, history, built heritage and/or if local values are integrated.

\section{Links between raw materials and emotional values}

An example of the aforementioned occurred at San José mine in 2010. In August of that year, 33 Chilean miners were trapped 720 meters below ground for 70 days before being rescued. The organization Fundación Imagen Chile stated that social networks mentioned the event in more than 3 million places; 12,000 photographs related to Chile and its miners were posted in the space of a week on Twitpic. It was the first time Chile was mentioned in such a massive and global scale. Ustream, the leading global provider of streaming, mentioned that this was their most watched news ever, with 5.3 million users between the 11 th and 12th of October, surpassing the death of Michael Jackson with 4.6 million and the inauguration of Barack Obama with 3.8 million.

Fundación Imagen of Chile, also carried out a study in Brazil, in which (although not explicit), it is interesting, to compare the perception of Brazilians about Chilean mining a year before and after the incident at San José; it is possible to observe how an emotional event can place in people's mind the perception that Chile is a mining country. Theories of cognitive science, like Donald Norman's, (Director of The Design Lab at the University of California, San Diego and author of Emotional Design) support the relevance that immaterial values can have on products. "What matters is the [...] associations that people have with the objects, and the memories they evoke" (Norman, 2004, p. 46); if people have an emotional connection to a country, they will, for example, have an opinion about it, and possibly buy things that represent its lifestyle. "Consumers tend to buy things that have meaning for them. The styles of objects you choose to buy and display often reflect public opinion" (Norman, 2004, p. 54).

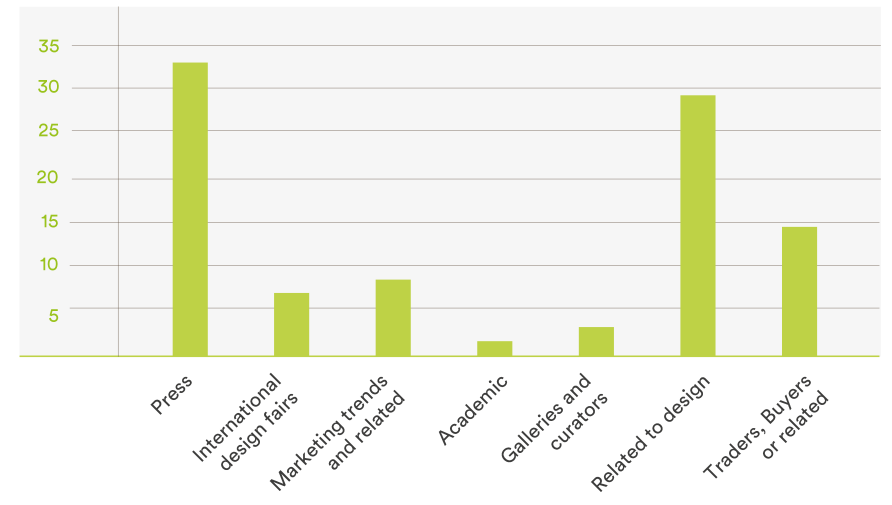

Fig. 5: Kind of visitors at Chile's pavilion, done by the author with records realized at ProChile 


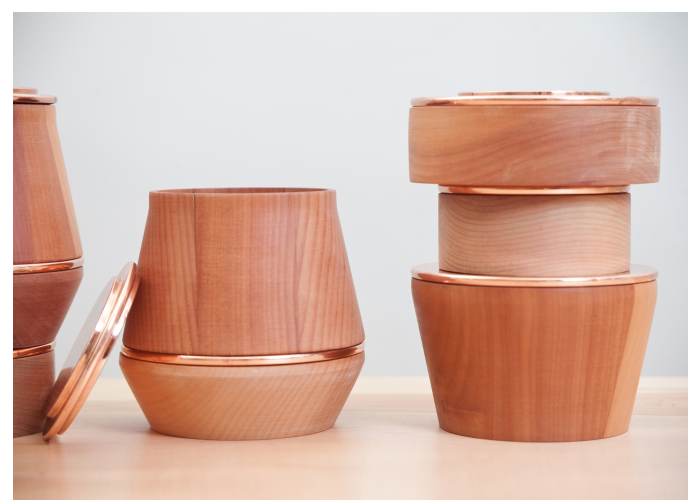

Fig. 6: La Familia by bravo! 2012

\section{Adding local values}

Thus, narratives can be added to activities related to the extraction of commodities, but this can be easier to understand if related to other common products, as the ones that are part of our daily life e.g. furniture, clothing, also a landscape, etc. Branding uses this, as it can be seen in the wine market. David Cohen, Daisy Dawson and Dr. Joanna Fountain, refer to the wine market and the importance of creating land narrative to evoke emotional connections (2011). Moreover, if the Chilean wine market recognition is compared with copper, it can be observed that wine exports reach USD 1,732 billion in contrast to the USD 40,333 billion generated by copper (refer to figure 2); but the former is more recognised as a Chilean product abroad than the latter, as it can be seen in

studies made by Fundacion Imagen de Chile, 2010, in seven different countries, Chile was mainly associated with wine production. It can be deduced that wine has been sold with an emotional narrative, which people can recall. The wine market contributes to overseas acknowledgment but it is necessary to increase the number of markets in which Chile is well recognised, in order to generate collective narratives.

\section{Chilean design studios, re-thinking heritage}

Design can also integrate value, using local raw materials; examples of this are some pioneer Chilean design studios which work with the recognition and enrichment of heritage so as to reinvent, interpret, integrate or create what could be called "new traditional", adding narrative processes and cultural values to Chile's main exports, such as copper and wood. In 2011, The Consejo Nacional de la Cultura y las Artes (CNCA), in charge of the Creative Industries, formed a design area for the first time, (Figueroa, 2014) whose aim is to support Chilean designers. One strategy was to present their works in international festivals.

As an example, at the London Design Festival 2012, the Dirección de asuntos culturales, (DIRAC) in charge of the cultural events of Chile abroad, in collaboration with CNCA and ProChile, placed a Chilean pavilion with six small studios, receiving around 100 people, mostly press, designers, and traders, as shown below.

One of the studios was bravo! They exhibited a set of containers called La familia, in which typical materials were used, in this case, copper and a special wood, Lenga, from the south of the country. They rescued Chilean carpentry techniques in a vital redefinition of such traditions.

The studio has also presented at the Salone Internazionale del Mobile Milano, Stockholm Furniture Fair, WantedDesign, New York, among others. (Bravo, 2016). Rodrigo Bravo (bravo's director) mentioned that be part of an international circuit allows them to appear in international magazines like DAMn, ICON, WGSN, and opens opportunities as being in shops like La Rinnacente (Milan), Mint Gallery (London) and Bensimon (Paris), Monoqi (Germany-Belgium). In Chile, they also created relevant projects as the interior architecture of Centro Cultural Gabriela Mistral (GAM) [One of the biggest cultural centres in Chile]. (Página 12, 2016).

At the same time, The Andes House studio, uses typical materials and traditional craft legacy, with new design shapes to reinvent the results to embody Chilean identity and preserve the knowledge of traditional craftsmen (Made in Mimbre, 2010). This studio has also represented Chile in the same exhibitions than bravo! and others like Bienal Iberoamericana in Madrid, MALBA Buenos Aires, Stockholm Furniture Fair and Llavoretes in Valencia, and the like (DIRAC, 2012) and published at Wallpaper*, dezeen, designboom, among others. The following graph shows the publications where these studios were mentioned a few weeks after the London Design Festival 2012 ended.

They also sell their products at Mint Gallery, Malba (Buenos Aires) and Puro Chile (New York). In relation to their incomes, it can be mentioned that on October 2012 they aimed to end the year with 17,4000 USD (120 million CLP), (Capital, 2012) which is good for a small

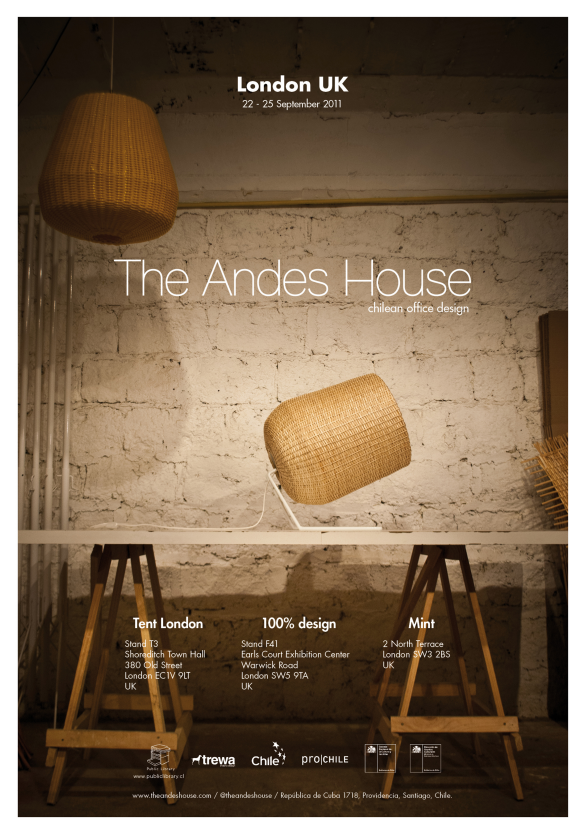

Fig. 7: The Andes House, promotional poster for the London Design Festival, 201 


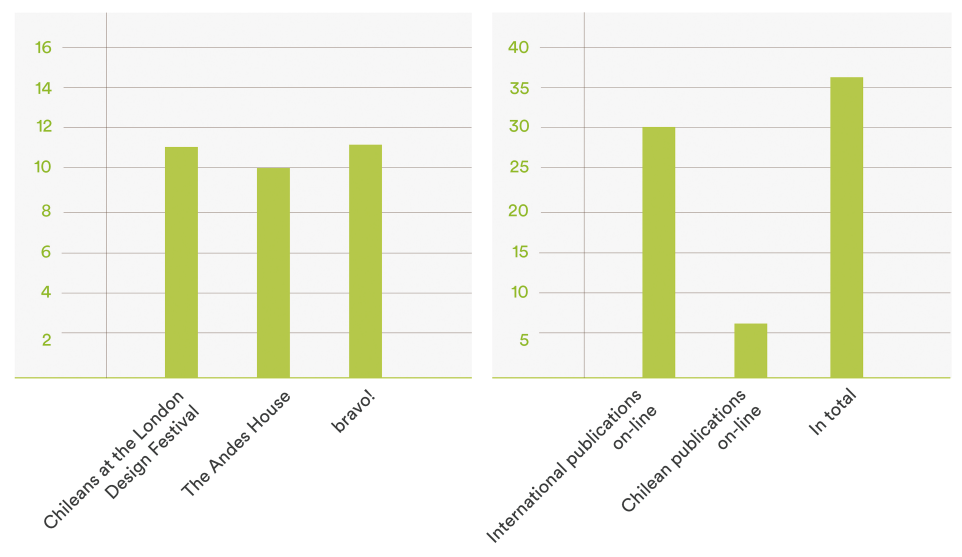

Fig. 8: Internet publications of Chileans in general, and by studio. Online publications; international, Chilean and in total. Both done by the author with records from ProChile
Chilean design studio.

It is important to continue efforts like this one to create relevant Chilean 'ambassadors'. If their products capture people's interest, it could help with the diffusion of the country and create connections in people's minds. This could increase the knowledge and awareness of Chilean products, lands and people. Also, it could lead Chile to invest in Design innovations, thus diversifying the market and weakening the dependency in economies based only on raw materials.

The Chilean scenario is changing, in 2014 , the $C N C A$, mentions that Creative Industries experienced a growth of $14 \%$ in the last 5

years. Conversely, Chile cannot continue basing its economy in one commodity. Vicente Mira (Vice-President of the Foreign Investment Committee) mentioned that Chile started moving towards a knowledge economy, trying to be less dependent on copper and focusing more on intensifying added value and services. (Mira, 2016).

\section{Conclusion}

In sum, Latin American Economies, are experiencing a tighter integration with Asia; however, this exchange is based primarily on finite natural resources. The increase in the export of these goods generates opportunities, but with risks. The example of the Chilean Economy, based on goods exported on a large scale, with China as its main buyer, makes Chile's economy dependent on China, thus vulnerable to a shortage or depletion of resources, the decline of demand, etc. Despite being the result of their effort, the exporting country and local workers go unnoticed. Nevertheless, this market opportunity offers the chance to acquire capital to invest in other sectors and diversify industries, which can, in turn, integrate cultural value and contribute to the international recognition, generating protection for its land and rural and primary populations. Design is a tool that can introduce value. It can help to strengthen a country's image by promoting new innovations, creating exports, and/or incorporating local narrative, hence, disseminating knowledge and local human capital. Thus, providing visibility and new income opportunities.

\section{References}

Anderson. S. (2012) '210 Minerals Year Book, Chile'. USGS, Science for changing world. Available: http://minerals.usgs.gov/minerals/pubs/country/2010/myb3-2010-ci.pdf, [22 Feb. 2013].

CAPITAL, (2012) 'Puro Talento' [Electronic], Available: http://www.capital.cl/negocios/2012/10/12/081020puro-talento-2 [9 May. 2012].

CNCA, (2014). 'Industria Creativa Nacional ha experimentado un crecimiento del 14\%en los últimos 5 años' [Electronic], Available: http://www.cultura.gob.cl/institucionales/consejo-de-la-cultura-presento-en-icareestudio-que-precisa-el-aporte-economico-de-la-industria-creativa-chilena/, [10 May. 2012].

Bravo, R. (rbravo@bravo.io). (2016, May 10). About bravo!. E-mail to Adriasola, Florencia (florenciadriasola01@gmail.com).

Chadwick, E. (2013) 'La Gestión de la Marca País en la Perspectiva de la Diplomacia Pública’ Seminario diplomacia e imagen país, [Electronic] Available: http://www.imagendechile.cl/wpcontent/uploads/2013/08/FICH-Presentacion-Seminario-ACADE-VL-Agosto-2013.pdf, [8 Feb. 1999].

Cohen, D., Dawson, D. \& Fountain, J. (2011) 'Place-based Marketing and Wine Tourism: Creating a Point of Difference and Economic Sustainability for Small Wineries' 6th AWBR International Conference, Bordeaux Management School. [Electronic] Available: http://academyofwinebusiness.com/wpcontent/uploads/2011/09/63-AWBR2011_Dawson_Fountain_Cohen.pdf [7 Mar. 2012].

Davis, H. (2014). 'Diplomacy in the Face of Gaia, A conversation with Bruno Latour' [Electronic], Available: https://www.academia.edu/18880502/Diplomacy in the Face of Gaia A conversation with Bruno Latour, [28 Mar. 2014]. 
DIRAC. (2012). 'Chilean Design Now! London Design Festival 20120' Press Release [Electronic], Available: http://diracpro.altavoz.net/prontus_dirac/site/artic/20121026/asocfile/20121026105828/press_release_2.pdf, [22 Jan. 2013].

Figueroa, M. (2016, May 10). Personal communication.

Fundación Imagen País. 'Las impresionantes cifras de cobertura mediática en la mina San José, Análisis cuantitativo' Fundación Imagen País, [Electronic] Available: http://www.imagendechile.cl/las-impresionantescifras-de-cobertura-mediatica-en-la-mina-san-jose/, [21 Feb. 2013].

Fundación Imagen de Chile. (2009 and 2011). 'Imagen de Chile en Brasil 2009-2011'. Serie de estudios imagen de Chile en países relevantes, [Electronic] Available: http://www.imagendechile.cl/wpcontent/uploads/2012/10/Imagen-de-Chile-Brasil.pdf, [19 Feb. 2013].

Fundación Imagen de Chile. (2010).'La Imagen Externa de Chile’ IV Encuentro Educación y Minería’ [PDF]. [22 Feb. 2013].

Lambregts, B., Beerepoot, N. \& Kloosterman, R. (2016), 'The local impact of globalization in South and Southeast Asia'. New York: Routledge.

Latour, B. (2013). 'An Inquiry into Modes of Existence: An Anthropology of the Moderns. Cambridge, Massachusetts: Harvard University.

Latour, B. (2011) 'Waiting for Gaia'. Composing the common world through arts and politics. SPEAP (Sciences Po-program in Arts \& Politics). [Electronic], Available: http://www.bruno-latour.fr/sites/default/files/124GAIA-LONDON-SPEAP_0.pdf, [28 Jan. 2013].

Lüders, R \& Wagner, G. (2003). 'Nitrate Export collapse and the Great Depression: Trigger or Chance?' Cuadernos de Economía [Electronic], vol.121 Available: http://www.economia.puc.cl/docs/121ludec.pdf, [14 Feb. 2013].

Maksaev, V. (2001).'Metalogénesis, Nitratos y salares'. [Electronic], Available: http://www.cec.uchile.cl/ vmaksaev/NITRATOS\%20Y\%20SALARES.pdf

Mira, V. (2016, February 3). Personal Interview.

Monteon, M. (1982). Chile in the Nitrate Era: The Evolution of Economic Dependence, 1880-1930. Madison: Univ of Wisconsin Press.

Norman, D. (2004). Emotional Design: Why we love (or hate) everyday things. New York. Basic Books.

Página 12. 'Bravo al Sur' [Electronic], Available: (2016). http://www.pagina12.com.ar/diario/suplementos/m2/10-3104-2016-04-30.html [10 May. 2016].

ProChile. (2012). 'The Chilean Economy: Facts and Figures' [Electronic], Available: http://www.prochile.cl/importadores/en/acerca-de-chile/informacion-economica.php, [5 Dec. 2012].

Strauss, S. (2012) 'Latin America and Asia: Globalization Trumps Power Politics'. Hemisphere, A magazine of the Americas [Electronic], vol. 21, pp. 6-8, Available: https://lacc.fiu.edu/hemisphere/hemisphere_vol_21.pdf, [28 Jan. 2013].

Turner, M. (2007). 'Chile - Venezuela: The Hidden Weakness of a Strong Economy' EconoMonitor [Electronic]. Available: http://www.economonitor.com/blog/2007/11/chile-venezuela-the-hidden-weakness-of-astrong-economy/\#idc-containe, [24 Dec. 2012]

UNESCO, (2003) 'Humberstone and Santa Laura Saltpeter Works', World Heritage Scanned Nominatio,n [Electronic], Available: http://whc.unesco.org/uploads/nominations/1178bis.pdf, [12 Feb. 2012].

UNESCO, (2005) 'Twenty-four New Sites Added to World Heritage List' The World Heritage, Newsletter, [Electronic], Available: whc.unesco.org/document/5951 2005, [12 Feb. 2012].

\section{Biographical note}

Florencia Adriasola, Designer, MA in Innovation Management at Central Saint Martins, London, UK. She worked with the Chilean Trade Commission in the UK (ProChile) supporting Chilean designers at the London Design Festival. She also taught at Universidad Católica de Chile (PUC) and is currently teaching at Universidad Diego Portales (UDP). 